KHAZANAH MULTIDISIPLIN

VOL 2 NO 12021

https://journal.uinsgd.ac.id/index.php/kl

\title{
PENGHAPUSAN PARTAI POLITIK DALAM METODE KETATANEGARAAN INDONESIA
}

\author{
Abdul Muiz Nuroni \\ Program Magister Prodi Ilmu Hukum Pasca Sarjana UIN Sunan Gunung \\ Djati Bandung, Indonesia \\ E-mail: Abdulmuiznuronihipo97@gmail.com
}

\begin{abstract}
As a state of law, Indonesia regulates all of aspects life including politics. In realizing a rule of law, politics has an important role. The aims of this study is to know how to abolish political parties without going through the application procedure to the Constitutional Court. Namely, filing a constitutional complaint. The governement has been breaks Constitutional complaints are based on the reason that freedom of association that contained in political parties, that guaranteed by Constitution of 1945. Guidelines that taken by the Constitutional Court should based on the principles of ius curia novit when dealing with political parties. The notice of ius curia novit principles is that a judge should not refuse to check and adjudicate a matter that has no legal reason or is unclear. Then the legal efforts taken in the process of dissolving the political party are twofold namely: 1) through filing a lawsuit to the state administration court. 2) filing a consttusinoal complain This research method uses a qualitative approach to data processed from the process of collecting library materials, then selected to produce specific data products related to the topic of the problem being studied, then selecting data in legal aspects in a logical order. Article data is compiled and analyzed using the deductive method.
\end{abstract}

Keywords: Political Parties, Constitutional Court.

\begin{abstract}
ABSTRAK
Indonesia sebagai negara hukum mengatur segala aspek kehidupan diantaranya aspek politik. Aspek politik ini berperan penting untuk mewujudkan suatu negara hukum. Adapun penelitian ini, untuk mengetahui bagaimana penghapusan partai politik dengan tidak melewati langkah pengajuan kepada Mahkamah Konstitusi. Yakni, mengajukan constitusional complaint. Pemerintah telah melanggar constitutional complaint yang berasaskan kebebasan berkongsi yang berwujud partai poliitik telah dijamin oleh undang undaang dasar 1945. Pedoman yang diambil oleh Mahkamah Konstitusi harus berdasarkan asass ius cuuria novit apabila menghadapi partai politik yang mengajukan constitutional complaint. Adapun maklumat dalam asas iuss cuuria novit adalah hakim pengadilan tidak diperkenankan memeriksa perkara dan mengadili perkara yang beralasan bahwa hukumnya (kabur) tidak jelas. Lantas upaya hukum yang ditempuh dalam proses penghapusan partai poltik ada dua yakni: 1) menggunakan upaya hukum gugatan kepada pengadilan tata usaha negara. 2) menggunakan upaya constitusinoal complaint. Metode penelitian yang digunakan adalah pendekatan kualitatif data diolah dari proses pengumpulan bahan-bahan kepustakaan, lalu diseleksi guna menghasilkan produk data khusus yang berhubungan dengan topik permasalahan yang dikaji, selanjutnya memilih data dalam aspek hukum secara berurutun logis. Data artikel disusun dan dianalisis dengan menggunakan metode deduktif.
\end{abstract}

Kata Kunci: Partai Politik, Mahkamah Konstitusi. 
KHAZANAH MULTIDISIPLIN

VOL 2 NO 12021

https://journal.uinsgd.ac.id/index.php/kl

\section{PENDAHULUAN}

Pasal 1 dan ayat 2 UUD Negara Kesatuan Republik Indonesia pada tahun 1945 yang berbunyi Kedaulatan sepenuhnya berada di tangan rakyat dan wajib dilaksanakan menurut undang undang dasar, menegaskan bahwa Indonesia ialah negara dengan kedaulatan rakyat. Partai Komunis Indonesia dan partai rakyat demokratik sebagai dua partai yang dibubarkan pemerintah menjadi perjalanan teristimewa sepanjang sejarah di Indonesia ${ }^{1}$. Surat keputusan nomor 1 maret 1996 dan SK menteri dalam negeri nomor pada 210 sampai 221 tahun 1997 menjadi dasar dihapuskannya Partai Komunis Indonesia dan Partai Rakyat Demokratik.

Sejak kemerdekaan, cita negara hukum pada konstitusi negara Indonesia merupakan hal yang tidak dapat dipisahkan dalam berkembangnya gagasan kenegaraan Indonesia. Akantetapi terkait dengan konsep rechts staat dan the rule oflaw, gagasan, cita atau ide suatu negara hukum juga berkaitan dengan konsep nomocracy dengan asal kata nomos dan cratos, istilah nomokrasi juga dapat dibedakan dengan demokrasi yang berasal dari kata istilah demos dan cratos atau kratien. Arti dari kata nomos adalah norma, dan cratos yang berarti kekuasaan. Norma atau hukum adalah yang dibayangkan sebagai faktor yang menunjukan dalam penyelenggaraan kekuasaan. Oleh sebab itu, sebagai kekuasaan tertinggi istilah nomokrasi, erat kaitannya dengan prinsip hukum atau ide kedaulatan hukum. Berdasarkan prinsip rule of law dalam bahasa Inggris yang dikembangkan oleh A.V. Dicey di Amerika Serikat dengan jargon the Rule of Law, and not of man yang mengandung makna bahwa yang menjadi pemimpin adalah negara hukum itu sendiri, bukan orang. Sesuai dengan buku yang dibuat oleh Plato yang berjudul "The Laws", telah jelas bahwa sesungguhnya ide nomokrasi tersebut sejak zaman Yunani Kuno telah dikembangkan.

Menurut Jimly Asshiddiqie, pilar utama untuk demokrasi adalah partai politik. Untuk itu, agar terciptanya demokrasi yang kokoh maka sebagai penopang partai politik haruslah kuat dan kokoh. Oleh karena itu dalam mengatur tata cara pendirian dan penghapusan partai politik, rambu-rambu hukum yang adil sangatlah diperlukan.

Sebagian besar orang di Indonesia yang mendirikan partai politik dalam pemerintahan bermaksud ingin mendapatkan jabatan atau kedudukan. Terkadang partai politik dimanfaatkan oleh pengurus partai sebagai alat politik menuju puncak kekuasaannya kemudian mengabaikan peran dari partai politik itu sendiri yakni sebagai pilar utama dalam demokrasi. undang undang nomor 2 tahun 2008 menjadi dasar dibentuknya partai politik. Atas dasarnya tersebut, tugas dan fungsi partai politik harus dilaksanakan dengan baik. Jika tidak dilaksanakan dengan baik, maka akan ada penghapusan atau penghapusan pada partai politik. Adapun alasan penghapusan partai politik tidak diatur tegas didalam undang undang nomor 2 tahun 2008 sehingga pada praktiknya tugas dan fungsi partai politik tidak dilaksanakan dengan baik oleh sebagian besar partai politik. Bahkan sampai saat ini, pengajuan permohonan penghapusan partai politik tidak pernah masuk ke Mahkamah Konstitusi di samping tugas Mahkamah Konstitusi yang memiliki wewenang dalam memutus penghapusan partai poltik.

Penghapusan partai politik menjadi wewenang Mahkamah

1 R. Hutabaarat, Politik Hukum Pemerintaahan Soeharto tentang Demookrasi Politik di Indonesia (1971 1997) Jakarta : Program Study HTN FH UI, 2005, hal. 31.

2 Plato, The laws, Penguin Classsics, edisi pada tahun : 1986. Yang diiterjemahkan oleh Trevor J. Saunders. 
KHAZANAH MULTIDISIPLIN

VOL 2 NO 12021

https://journal.uinsgd.ac.id/index.php/kl

Konstitusi setelah Mahkamah dimiliki oleh Indonesia. Penghapusan partai politik tersebut merupakan Mahkamah konstituis yang memiliki pelaksanaan kekuasaan kehakiman. Mahkamah konstitusi dapat mengadili dihapuskannya partai politik serta UUD 1945 memberikan kewenangan dalam sengketa lembaga negara apabila dua atau lebih lembaga negara terlibat di dalamnya. Adanya undang undang nomor 24 tahun 2003 tentang Mahkamah Konstitusi pada kenyataannya tidak menjadi penyelesaian kewenangan Mahkamah Konstitusi terhadap penghapusan partai politik yang tertuang dalam undang undang nomor 31 tahun 2002. Dalam analisis ini penulis menemukan permasalahan terkait tema diatas yaitu bagaimana upaya hukum yang ditempuh oleh partai politik kepada Mahkamah Konstitusi? Dan bagaimana proses penghapusan partai politik dengan tidak melewati proses pengajuan kepada mahkamah Konstitusi?

\section{METODE PENELITIAN}

Pendekatan kualitatif merupakan pendekatan yang sering digunakan pada umumnya, maka penulis akan menggunakan penelitian melalui pendekatan kualitatif, yaitu dengan cara mengolah data dari proses pengumpulan bahan-bahan kepustakaan, lalu diseleksi guna menghasilkan produk data khusus yang berhubungan dengan topic masalah yang dikaji, selanjutnya memilih data dalam aspek hukum secara berurutun logis. Data artikel ini disusun dan dianalisis dengan menggunakan metode deduktif. Selanjutnya, data tersbeut ditafsirkan menggunakan cara penafsiran sistematis, yakni menginterprestasi makna lalu mengaitkan norma hukum satu dengan norma lain yang dianggap memiliki keterkaitan yakni normanorma hukum yang ditentukan sebagai bahan utama maupun pelengkap dalam artikel ini.

\section{HASIL DAN PEMBAHASAN}

\section{Makna dan Hakikat Partai Politik}

Partai dan politik terdiri atas dua kata yang tidak bisa dipisahkan. Kata partai lebih merujuk kepada pengelompokan atau sebagai golongan yang berdasarkan kesesuaian tertentu, seperti haluan, ideologi, religi, 
KHAZANAH MULTIDISIPLIN

VOL 2 NO 12021

https://journal.uinsgd.ac.id/index.php/kl

bahkan kepentingan. ${ }^{3}$ Secara global penggolongan merupakan suatu organisasi secara global, dapat dibedakan menurut distrik aktivitasnya, seperti ormas, organisasi religi, organisasi perdesaan seperti karang taruna, serta organisasi politik. Dengan ciri politik berarti pengelompokkan yang beraliih di bidang politik.

Partai poltik merupakan sekelompok anggota anggota yang mempunyai orientasi, nilai nilai, dan angan-angan yang terstruktur. Partai politik bertujuan untuk mendapatkan kekuaasaan politik dan merampas tahta politik. Menurut (Miriam budiarjo, 2003). Biasanya hanya dengan aturan konstitusional untuk melaksanakan kebijaksanaan serta kearifan mereka. $^{4}$

Partai politik merupakan sekelompok organisasi yang dibuat oleh sekelompok warga negara Indonesia secara bebas atas dasar kemauan kebersamaan dan tujuan untuk membela dan melepaskan kepentingan politik anggota yang bersifat nasional, bangsa dan negara berkewajiban untuk memelihara keutuhan bangsa Republik Indonesia atas dasar Pancasila dan undang undang dasar negara republik Indonesia tahun 1945 berdasarkan pasal 1 angka 1 undang undang nomor 2 tahun 2008 tentang partai politik.

Terdapat beberapa teori penjelasan asal usul partai politik: $:^{5}$ Teori birokrasi menggambarkan adanya hubungan antara badn legislatif dan timbulnya partai politik. Teori keadaan historik, metode politik untuk mengatasi krisis yang meinimbulkan adanya perubahan yang secara luas masyarakat melihat timbulnya partai politik sebagai upaya. Teori partai politik pembangunan yang sebagai produk kemajuan ekonomi sosial.

Metode kepartaian terdapat beberapa jenis jenis yang dapat diikuti

\footnotetext{
${ }^{3}$ TP-HAMK, Hukum Acara Mahkamah Konstitusi. Jakarat : Sekjen Kepanitraan, MK-RI, 2010, hlm. 193.

${ }^{4}$ Budiardjo, M. Dasar dasar IImu Politik. PT Gramedia Pustaka Utama, Jakarta : 2003, hal,161.

${ }^{5}$ Asshiddiqie, J. Konstitusi dan Konstitusionalitas Indonesia, Sekjen dan Kepanitraan Mahkmah Konstitusi RI, Jakarta : 2006, hal, 10.
} 
oleh suatu negara, yaitu pertama metode monopartai, kedua metode gandapartai dan ketiga metode multipartai. Metode monopartai diaplikasikan manakala partai yang berkepentingan betul-betul merupakan salah satu partai dalam negara, ataupun partai yang berpengaruh dalam kedudukannya yang diantara beberapa partai lainnya. ${ }^{6}$

Metode gandapartai dapat mempengaruhi oleh metode politik yang dimana dalam pemilihan pada umumnya dan didasarkan pada aturan pemenang mengambil semuanya. Kandidat yang mendapatkan suara paling banyak dan memenangkan pemilihan, maka tidak memandang perbandingan perolehan suara secara keseluruhan. ${ }^{7}$ Akan tetapi, ada tiga syarat yang harus dipenuhi terhadap dua metode partai politik, yaitu pertama: komposisi masyarakat yang mengikuti gaya hidup berwatak budaya atau homogen; kedua, konsensus dalam masyarakat mengenai asas dan tujuan sosial yang cukup kokoh dan kuat; ketiga, adanya kesinambungan sejarah yang menjadi dasarnya. metode gandapartai diperkuat pada umumnya dengan digunakannya sistem pemilihan adalah metode distrik, dimana dalam setiap daerah pemilihan hanya berhak mewakilkan seorang saja. ${ }^{8}$

Metode multipartai ini semakin membayangkan pluralitas budaya dan politik. metode tersebut bilamana berhubungan dengan sistem pemerintahan badan legislatif yang memiliki kecenderungan untuk mempokuskan kepada kekuasaan badan legislatif yang sehingga peranan badan eksekutif sering lemah dan was-was. Maka metode multipartailah yang harus diperkuat pada umumnya oleh metode pemelihan perwakilan yang berimbang memberikan kesempatan yang lebih luas bagi pertumbuhan partai dan golongan kecil. ${ }^{9}$

\footnotetext{
${ }^{6}$ Budiardjo, M. op.cit. hal, 167.

${ }^{7}$ Ibid. hal. 167.

8 Ibid. hal. 82.

${ }^{9}$ Ibid. hal. 170.
} 
KHAZANAH MULTIDISIPLIN

VOL 2 NO 12021

https://journal.uinsgd.ac.id/index.php/kl

\section{Makna Partai Politik}

Partai politik sendiri mempunyai makna berlainan antara partai politik yang satu dan yang lainnya. Dilihat secara garis besar, menurut Abdul Bari dkk., kewajiban partai politik, yaitu sebagai berikut: ${ }^{10}$

Pertama yaitu, sebagai sosialisasi politik partai politik harus mempunyai peran. Peran partai politik menjadi sorotan utama media yang menyebabkan seseorang memperoleh sikap dan orientasi terhadap fenomena dan kejadian politik, yang pada umumnya berlaku dalam masyarakat tempat ia berada.

Kedua yaitu, Partai politik harus dijadikan sebagai alat mobilisasi warga negara dalam kehidupan dan kegiatan politik yang disebut dengan partisipasi politik.

Ketiga yaitu, Partai politik berperan untuk merekrut orang yang berpotensi pemerintahan serta berperan aktif dalam berbagai kegiatan politik sebagai anggota partai. Dengan demikian, partai ikut memperluas partisipasi politiknya dengan caranya mendapatkan perlakukan melalui kontak pribadi ataupun dengan bujukan. Selain itu, juga diupayakan untuk mengangkat para generasi muda untuk dibimbing menjadi kader pada masa mendatang yang akan menggeserkan pimpinan sebelumnya. Kemudian, kader di ikutsertakan dalam pemilihan umum serta bersaing dengan partai politik lainnya untuk berkedudukan politik di badan eksekutif, legislatif, kementerian, pemerintahan provinsi, ataupun pemerintahan wilayah kabupaten.

Keempat yaitu, partai politik berkewajiban menjalankan komunikasi politik, dalam beromunikasi partai politik mengeluarkan beragaam pendapat dan aspirasi dari masyarakat, serta mengaturnya sedemikian rupa sehingga tidak terjadi moratmarit aspirasi dalam masyarakat berkurang sehingga tidak ada indikasi bahwa kebijakan pemerintah tidak diberikan kepada masyarakat. ${ }^{10}$ Baari Azed, A. dan Amiir, M. Pemilu dan Partai Politik di Indonesia, Jakarta : Pusat Study HTN
FH UI, 2005, hal.36. 
Kelima yaitu, mengujarkan kehendak tertentu kepada badan politik dan pemerintah melalui kelompok yang telah dibuat bersama dengan pihak lain yang memiliki kehendak bersama.

Keenam yaitu, melakukan upaya yang dilancarkan oleh sekelompok yang berbeda kemudian digabungkan menjadi preferensi kearifan pemerintah. Dalam masyarakat yang demokratis, partai politik merumuskan program politiknya dan menyampaikan usulan kepada parlemen dan calon yang diajukan untuk jabatan pemerintah mengadakan tawaran bersama kelompok lainnya. Dalam berbagai kepentingan mereka saling menawarkan bagi calon dari partai politik yang menawarkan apabila mereka mendukung kepentingan kelompok calon tersebut.

Strategi penyelenggara yakni, partai politik pasti akan berupaya untuk merampas kekuasaan dalam pemerintahan secara konstitusional. Setelah merampas kekuasaan maka dalam pemerintahan, baik dalam bidang eksekutif maupun bidang legislatif, akan ada pengaruhnya dalam mencipta kearifan yang akan digunakan dalam suatu pemerintahan.

\section{Sistem Penghapusan Partai Politik}

Menurut jimly Asshiddiqie ada beberapa hal terkait dengan penghapusan partai politik, yaitu sebagai berikut ${ }^{11}$ :

Indonesia belum diatur dengan jelas atas alasan penghapusannya partai poltik, baik yang telah diatur oleh undang undang pada nomor 31 tahun 2002 atau diatur oleh undang undang nomor 24 tahun 2003. Namun, ketentuannya hanya terdapat kedalam pasal 28 ayat 6 undang undang pada nomor 31 tahun 2002 yang menentukan alasan hukum bagi partai politik untuk menghapuskan partai politiknya.

Sebagai pengurus partai poltik yang menggunakan partainya untuk melakukan kegaduhan terhadap pemerintah sebagaimana yang dimaksud pasal 19 ayat 5 yang dituntut atas dasar undang undang nomor 27 tahun

11 Asshiddiqie, J. Kemerdekaan Berserikat, terhadap Pembubaran Partai Politik, dan Mahkamah Konstitusi, Jakarta : Konstitusi Perss, 2005, hal. 120. 
KHAZANAH MULTIDISIPLIN

VOL 2 NO 12021

https://journal.uinsgd.ac.id/index.php/kl

1999 permasalahan tentang perubahan kuhp yang berhubungan dengan kejahatan terhadap keamanan negara yakni dalam pasal 107 huruf c, huruf d, dan huruf e, dan partainya yang dapat dihapuskan secara konstitusi.

Berkaitan dengan aktivitasnya yang menyebarkan, mengembangkan, mendirikan organisasi yang mengikuti ajaran komunisme atau marxisme lenimisme, atau mengadakan hubungan dengan organisasi yang berdasarkan komunisme atau marxisme lenimisme yang berisikan tentang tindak Pidana maka diatur dengan jelas oleh pasal 107 huruf c, huruf d, dan huruf e, undang undang nomor 27 tahun 1999 berhubungan dengan kejahatan terhadap keamanan negara.

Seperti dimaksud yang ditetapkan oleh ketetapan Majeelis Permusyaawaratan Rakyat sementara nomor XXV MPRS 1966 pada Pasal 19 ayat 5 undang undang nomor 31 tahun 2002 menjelaskan, partai politik dilarang keras mempercayai, mengembangkan, atau menyebarkan ajaran atau pemahaman seperti ajaran komusime marxisme lenimisme.

Kemudian, diatur dalam pasal 19 ayat 5 diatur pada Pasal 28 ayat 6 undang undang nomor 31 tahun 2002 pelanggaran terhadap larangan ketentuan ideologis. Dapat dikenakan dua bentuk sanksi, bahwa partai politik yang telah melanggar ketentuan pasal 19 ayat 5 berdasarkan pasal 28 ayat 6, yaitu:

Pertama, pengurus partai poltik yang melakukan tindak pidana yang dimaksud pada pasal 107 huruf c, huruf d, dan huruf e, Kuhp sebagaimana telah direvisi oleh undang undang nomor 27 tahun 1999, atau;

Kedua, pada pasal 20 huruf c, undang undang nomor 31 tahun 2002 Mahkamah konstitusi dalam kewenangannya menghapuskan partai politik.

\section{Upaya Hukum Partai Politik}

Upaya hukum yang digunakan dalam permasalahan terkait 
KHAZANAH MULTIDISIPLIN

VOL 2 NO 12021

https://journal.uinsgd.ac.id/index.php/kl

penghapusan partai politik ada dua pengajuan ${ }^{12}$ :

\section{Berupaya mengajukan gugatan tata usaha negara}

Upaya yang ditempuh bagi partai politik yang melanggar dan dihapuskan oleh pemerintah tanpa melalui proses permohonan kepada Mahkamah Konstitusi dan dengan berupaya mengajukan proses gugatan melalui penyelesaian peradiilan tata usaha negara. Maka penyelesaian melalui peradilan tata usaha negara terdapat beberapa hal penting yang perlu diperhatikan.

Berupaya mengedepankan gugatan melalui peradiilan tata usaha negara terhadap yang telah menerbitkan keputusan tata usaha negara tentang penghapusan partai politik. Gugatan terhadap keputusan tata usaha negara yang telah diatur oleh undang undang nomor 5 tahun 1986 tentang peradiilan tata usaha negara, kemudian telah direvisinya undang undang nomor 9 tahun 2004 atas perubahan undang undang nomor 5 tahun 1986 mengenai peradiilan tata usaha negara.

Berupaya mengedepankan proses gugatan melalui peradiilan tata usaha negara bukan berarti tidak ada kekurangan dalam menyelesaikan sengketanya yang pasti ada kekurangannya. Kekurangan yang dihadapi pada saat proses gugatan tata usaha negara adalah waktu yang cukup lumayan lama dalam proses pengadiilannya dan harus menunggu sampai keluarnya putusan pengadiilan yang berkekuatan hukum tetap. Kemudian, dalam proses menyelesaikan sengketa tata usaha negara menghabiskan waktu paling cepat 6 (enam) bulan.

\section{Berupaya mengedepankan pengaduan konstitusi (Constitusional Complaint)}

Terkait pengaduan konstitusi atau yang disebut dengan constitusional complaint memang di negara Indonesia merupakan sesuatu

${ }^{12}$ U. Rasyidin dan A. Rusdiana, Pengantar Hukum Acara Mahkaamah konstitusi, Bandung : CV Pustaka Setia, 2018, hlm. 288-290. 
yang belum terdengar, meskipun bukan sesuatu yang aktual, karena belum ada instrumen hukum yang dapat mewadahinya. Menurut (Mahfud 2003), Menyelesaikan perkara ke Lembaga Mahkamah Konstitusi atas terjadinya pelanggaran hak Konstitusional yang tidak ada instrumen hukum atas terjadi sengketa atau tidak tersedia lagi diatasnya jalur proses penyelesaian hukumnya yang disebut dengan constitusional complaint.

\section{SIMPULAN}

Dari pembahasan tersebut maka penulis akan menarik kesimpulan mengenai Penghapusan persoalan partai poltik tanpa melalui proses yang berupaya mengajukan constitusional complaint ke Mahkamah Konstitusi. Kemudian pelanggaran pemerintah terhadap yang telah melanggar constitusional complaint dengan alasan bahwa undang undang dasar 1945 telah menjamin kebebasan berkongsi yang berwujud dalam bentuk partai politik. Dalam menghadapi partai politik yang mengajukan constitusional complaint sikap yang harus diambil oleh Mahkamah Konstitusi berpedoman pada asas iuss curia novit. Hakim pengadilan tidak diperkenankan untuk menolak perkara, memeriksa perkara dan mengadili perkara yang dengan alasan hukumnya (kabur) tidak jelas yang merupakan pernyataan dalam asas iuss curia novit. Adapun kewajiban hakim adalah menyelesaikan perkara dan menggali akar permasalahan sehingga perkara tersebut dapat dipecahkan, mengikuti alurnya perkara serta dapat memahami nilai nilai hukum yang terdapat dalam lingkungan masyarrakat. Mahkaamah Konstitusi tidak dapat beralasan untuk tidak menjawab Constitusional Complaint yang telah diajukan kepadanya apabila berpedoman kepada asas iuss curia novit.

\section{DAFTAR PUSTAKA}

Asshiddiqie Jimly. 2006. Konstitusi dan Konstitusionalitas Indonesia. Sekertariat jenderal dan Kepanitraan Mahkmah Konstitusi RI: Jakarta.

Asshiddiqie Jimly. 2005. Kemerdekaan Berserikat, Pembubaran Partai 
KHAZANAH MULTIDISIPLIN

VOL 2 NO 12021

https://journal.uinsgd.ac.id/index.php/kl

Politik, dan Mahkamah Konstitusi. Jakarta : Konstitusi Perss.

Budiardjo Miriam. 2003. Dasar-dasar Ilmu Politik. PT Gramedia Pustaka Utama, Jakarta.

Bari Abdul Azed dan Amir Makmur. 2005. Pemilu dan Partai Politik di Indonesia. Jakarta : Pusat Studi Hukum Tata Negara Fakultas Hukum Universitas Indonesia.

Hutabarat Ramly. 2005. Politik Hukum Pemerintahan Soekarno tentang Demokrasi Politik di Indonesia. 1971-1997. Jakarta : Pusat Studi Hukum Tata Negara Fakultas Hukum Universitas Indonesia.

Mahfud, M.D.M. 2012. Membangun Politik Hukum, Menegakkan Konstitusi. Jakarta: PT. Raja Grafindo Persada.

Plato, The laws. Penguin Classics, edisi tahun : 1986. Diterjemahkan dan diberi kata pengantar oleh Trevor J. Saunders.

TP-HAMK. 2010. Hukum Acara Mahkamah Konstitusi, Jakarat: Sekjen Kepanitraan, MK-RI.

Rasyidin U dan Rusdiana A. 2018. Pengantar Hukum Acara Mahkamah konstitusi. Bandung : CV Pustaka Setia. 